Arab Univ. J. Agric. Sci., Ain Shams Univ., Cairo, Egypt 28(2), 537-545, 2020

Website: http://ajs.journals.ekb.eg

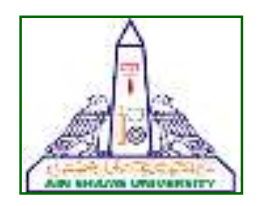

\title{
STUDIES ON COMPATIBILITY, FRUIT SET AND FRUIT QUALITY BY DIFFERENT POLLINATORS IN ANNA APPLE CULTIVAR
}

\author{
Mai I. Anwar ${ }^{1}$, Abdel-Ghany ${ }^{2}$ N.A., Maklad ${ }^{2}{ }^{*}$ M.F. and Nahla A. Awad ${ }^{1}$ \\ 1- Breeding Research Dept., of Fruit Trees, Ornamental and Woody Plants, Horticulture \\ Research Institute, Agricultural Research Center, Giza, Egypt \\ 2- Horticulture Dept., Fac. of Agric., Ain Shams Univ., P.O. Box 68, Hadayek Shoubra 11241, \\ Cairo, Egypt
}

*Corresponding author: mahmoud maklad@agr.asu.edu.eg

Received 18 June, 2020

Accepted 24 August, 2020

\begin{abstract}
The apple (Malus domestica) is a member of the Rosaceae family. It is older than the rose in cultivation and is often referred to as the prince of the rose family. Pollen grains of Dorsett Golden, E25 and Ein Shemer were used to investigate their compatibility and incompatibility with Anna cultivar under the Egyptian climatic conditions during two successive experimental seasons of 2016 and 2017. The fluorescence microscope was used to determine the degree of pollen tube growth in style tissue after specific pollination treatments. Degree of self and cross compatibility and or incompatibility were determined, initial, and final fruit set percentage were calculated. Pollination treatments revealed that, pollens of the four apple cultivars exhibited high rate of the viability after $24 \mathrm{hr}$. in T.T.C test. Growth of pollen tube of the tested cultivars exhibited different pattern of compatibility, the pollen tubes of Dorsett Golden and Ein Shemer cultivars showed different levels of cross-compatibility when fertilized in Anna style tissue. The pollen tube of E25 cultivar grew slowly with heavy deposition of calluses along to the tube where its growth stopped in the lower part of Anna style four days after pollination. Therefore, they need pollinizer cultivars as for good fruit set. On the other hand, Anna self-pollination seemed to be self-incompatible and recorded lowest initial of fruit set percentage in the first and second seasons. The combinations of Anna $\times$ Dorsett Golden exhibited maximum percentage of initial and final fruit set in the two seasons followed by Ein Shemer pollens in both seasons. Insignificant differences were noted in fruit weight and fruit volume among all
\end{abstract}

crosses. The highest acidity was found in hybrid Anna $\times$ Dorsett Golden in except in the first season TSS values of these crosses were not high and ranged between $11.83 \%$ and $12.83 \%$.

Keywords: Apple cultivars, Anna, Cross-compatibility, Pollen viability, Fruit set, Fruit quality

\section{INTRODUCTION}

Pollination is an important step in apple quality manufacturing. Although many environmental factors can result in poor pollination and lower fruit setting, the genetic makeup and quality of an orchard's apple varieties are key determinants of pollination success. The cultivated apple (Malus $x$ domestica) and several other economically significant members of the Rosaceae or rose family (pears, peaches, prunes, sweet and tart cherry) contain a complex biochemical mechanism that prevents the ovules from being fertilized by the variety's own (also known as cultivar) pollen, the initial phase in fruit growth (Hua et al 2008). This method, known as self-incompatibility (SI), places a lot of restrictions on both the apple grower and breeder, but it does have the benefit of keeping apple versatile. For a so-called "outcrosser," this means that apple offspring differ from their parents, allowing them more capacity to respond to illness and stress. In the past few decades, self- and cross-incompatibility has grown, and new methods (molecular markers) are available to help the SI 's challenges (Orcheski and Brown, 2012). Structures of self-incompatibility (SI) can be classified into two main groups: Gametophytic Self-Incompatibility (GSI) and SSI. (Maryam Bagheri and 
Ahmad Ershadi, 2019). GSI is the most frequent type of SI in the Solanaceae, Rosaceae and Papaveraceae families (De Nettancourt 2001). Commercial fruit in pear orchards is cross-pollinated and requires at least two compatible cultivars that flower simultaneously to produce fruit (Zisovich et al 2010). Apple has a gametophytic incompatibility multi-allelic system controlled by a single $S$ gene (Frankel et al 1977). Several apple cultivars are considered to be mutually incompatible (Ishiyama et al 1995; Way, 1995 and Sakurai et al 2000). Incompatibility and compatibility between parents (female and male parents) are important factors in the crop production (Abou EI Nasr et al 1997).

In this respect, Anna apple cultivar (as a female parent) was investigated for their self, cross-compatibility and or incompatibility level between Dorsett Golden, E25 and Ein Shemer which uses as pollinizers for Anna cultivar to improve fruit set and fruiting.

\section{MATERIALS AND METHODS}

\section{Plant materials}

This study was conducted during two consecutive seasons of 2016 and 2017 at the private orchard, El-Sadat city, Monefeia governorate. Three cultivars of Apple namely, Dorsett Golden, E25 and Ein Shemer were used to evaluate pollen tube growth as potential factors limiting apple fruit set parameters and, to define the effective pollinizer for Anna apple cultivar (as a female parent). Therefore, the following crosses had been done:

a. Anna selfing pollination.

b. Cross pollination by Dorsett Golden pollens.

c. Cross pollination by E25 pollens d. Cross pollination by Ein Shemer pollens.

e. Anna open pollination as a control.

\section{Methods}

\section{(1) Pollen viability}

Anthers of the four cultivars studied were collected at the balloon stage from the flowers and held at room temperature on paper sheets throughout the night, to promote dehiscence. Pollen viability was calculated using a staining solution of $2,3,5$ triphenyl tetrazolium chloride (T.T.C) (1 part 10\% T.T.C.: 10 part $60 \%$ sucrose) according to Oberle and Watson (1952).

\section{(2) Pollination experiments}

On Anna trees (as a female parent) self-pollination and cross-pollination were carried out, ten Anna female parents were identical in vigor and size and the same bearing process as much as possible in randomized full block design, 6 panicles (panicle as a one replicate) from each tree were chosen to conduct the combination by each tested pollinate male parent. Flowers were selected at a similar stage of development, each panicle was well bagged with a pergamin bag before anthesis to prevent insect pollination and the pollen grains of each pollinator were collected for hand pollination after emasculation (cross-pollination), then each panicle was bagged after being pollinated in pergamin bags. Four another of Anna panicles were chosen for each pollinate male parent from each tree and left until fruit setting. At anthesis and at the balloon stage, the number of total flowers was numbered. After 3 weeks of pollination (initial fruit set) or anthesis time and 2 weeks before harvest (final fruit set) number of stetted fruits was counted. The percentage of the initial and final fruit collection for different pollination treatments was determined as follows:

Percentage of initial fruit set $=$ (Number of fruitlets $/$ total number of flowers) $\times 100$.

Percentage of final fruit set $=($ Number of stetted fruits / total number of flowers) $\times 100$. In open pollination treatment, enough panicles were labeled without any treatment and the flowers were left under the natural conditions of the orchard.

\section{(3) Microscopic preparations}

From each combination, fifteen pistils/panicle collected just After pollination and set in FPA for seven consecutive days after pollination (Formalin: propionic acid: alcohol, 90:5:5). Pistil samples were softened in $8 \mathrm{~N} \mathrm{NaOH}$ for 2 hours, washed in distilled water for 24 hours and dyed in $0.1 \%$ aniline blue (W / S), dissolved in $0.1 \mathrm{~N} \mathrm{K3PO4}$ and analyzed with Leica fluorescence microscope (WILD LEITZ GMBH, 020-505-030, LEITZ WETZLAR GERMANY) according to the method of Kho and Baer (1970) and Maklad (2015).

Pomological characteristics of fruit from hybridization: including physical fruit properties i.e. the weight of the fruit $(\mathrm{gm})$, volume $\left(\mathrm{cm}^{3}\right)$, fruit length, fruit diameter in cm, number of seeds/fruit, fruit pulp thickness and some chemical properties including T.S.S\% and acidity according to A.O.A.C (1990) as $\mathrm{g}$ malic acid / $100 \mathrm{ml}$ flesh. 

in anna apple cultivar

\section{Statistical analysis}

For each pollination procedure, the experimental design was a complete randomized block with 10 trees and 6 panicles per branch (panicle as one replicate). The data collected during the two seasons have been statistically analyzed using the variance analysis (Snedecor and Cochran, 1972) means differentiated by 5 percent using the multirange test of Duncan (Duncan, 1955).

\section{RESULTS AND DISCUSSION}

\section{Pollen viability}

Table (1) illustrate the pollen viability of Dorsett Golden, E25, Ein Shemer and Anna apple cultivars in the two seasons of this research. Pollens of the Dorsett Golden apple cultivar exhibited highest significant rate of the viability after $24 \mathrm{hr}$. in T.T.C during two seasons. On the other side, there was no significant difference between E25, Ein Shemer and Anna cultivars in the second season. On the contrary, Anna cv. exhibited significantly lower viability of pollen grains (after $24 \mathrm{hrs}$.) than the other cultivars in the first season. Generally, the differences among cultivars were slight with significant differences in the two seasons. Thus, the two cultivars produced viable or fertile pollen grains. In this respect Ciprian et al (2012) Pollination is important biological element in apple production, and the viability and germination of pollen are two fundamental rings that signify the productive capacity of a cultivar. Pollen viability reported statistically differences between most varieties and control. 'Pinova' showed the highest pollen viability values (89.92\%), 'Gala' (80.48\%), 'Florina' (76.67\%), 'Topaz' (75.97\%) and 'Top Red' (74.64\%), with very substantial positive differences, compared to the others. There were no statistically confirmed differences in the percentage of pollen germination as opposed to the control except for 'Jonagold' with a noticeable negative difference.
Table 1. Pollen grains viability in T.T.C of Dorsett Golden, E25, Ein Shemer and Anna apple cultivars in 2016 and 2017 seasons

\begin{tabular}{|c|c|c|}
\hline $\begin{array}{c}\text { Percentage of the valiability of pollen grains in } \\
\text { T.T.C after 24h. }\end{array}$ \\
\hline & Season 2016 & Season 2017 \\
\hline Dorsett Golden & $94.28 \mathrm{~A}$ & $95.49 \mathrm{~A}$ \\
E25 & $90.60 \mathrm{BC}$ & $90.92 \mathrm{~B}$ \\
Ein Shemer & $91.79 \mathrm{~B}$ & $91.69 \mathrm{~B}$ \\
Anna & $89.33 \mathrm{C}$ & $89.85 \mathrm{~B}$ \\
\hline
\end{tabular}

Values having the same letter within the same column are not statically different at $5 \%$ level

\section{Compatible pollinator efficiency}

\section{Cross compatibility and/or incompatibility}

Microscopic examination showed growth of pollen tube in pistil after cross-pollination, pollen tubes of Dorsett Golden and Ein Shemer cultivars showed levels of cross-compatibility when fertilized Anna styles; some of the pollen tubes of Dorsett Golden and Ein Shemer showed in the upper part of the style, they were visible and reached the end of the style after 3 days from pollination (Fig.1). Nevertheless, in Anna styles when pollinated with E25 pollens in the most cases, some of the styles showed abnormal pollen tube growth which grew by spacing the callus plugs along the tube through the styles and reached the lower part of the style four days after pollination (Fig. 2 A-C). On the same side, although most pollen grains of E25 cultivar has germinated on stigma surface, the pollen tube grew slowly with heavy deposition of calluses along to the tube where its growth stopped 4 days after pollination in the lower part of the style.(Fig. 2 D-F). Partial Cross-incompatibility was observed when Anna cv. flowers were pollinated with E25 pollens. Some of the styles showed normal Based on the obtained results. In addition, when pollinated with E25 pollen grains Anna cultivar showed cross-incompatibility. 
In addition, the presence of short tubes from E25, which could not penetrate Anna pistil's stigma, as well as the twisting tube as shown in (Fig. 2). However, most pollen tubes, which formed at the end of the pollen tube (Fig. 2) through the types defined by terminal calluses plugs. Semi-compatible cultivars sharing one of their S-alleles were widely cultivated together in the same orchards, which are not always optimal (Hegedûs, 2006). Incompatibility systems are generally classified as gametophytic or sporophytic depending on whether the incompatibility reaction with the maternal tissue is mediated by the haploid pollen grain genotype (gametophytic) or the diploid anther genotype which produced the pollen (sporophytic) (Anne, 2007).
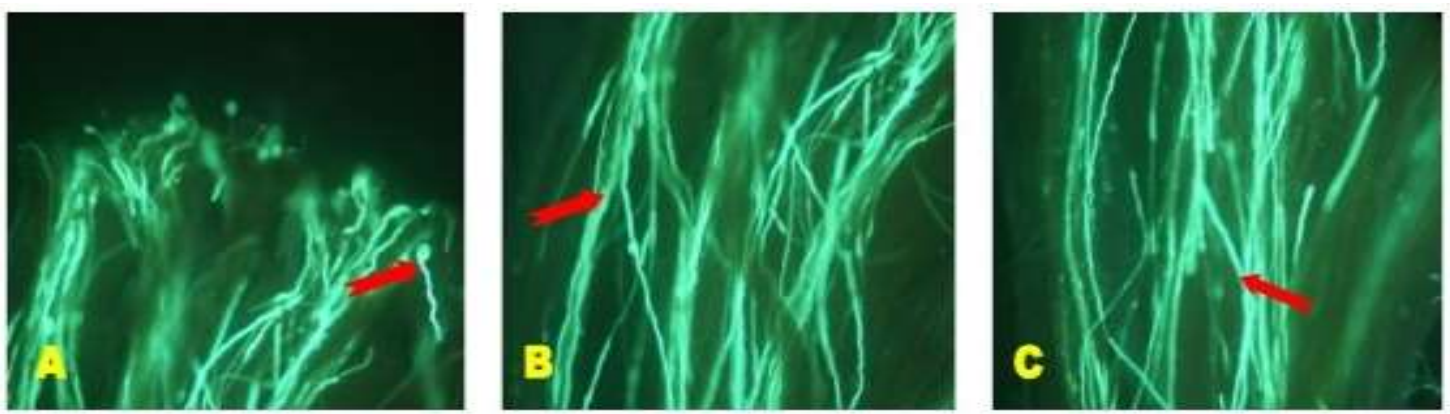

Fig. 1. Pollen tube characteristics after compatible crosses (Anna* Dorset Golden and Anna* Ein Shimer)

a) Pollen tubes were visible in the upper part of the style (X100)

b) Pollen tubes grew to the $1 / 2$ of the style length two days after pollination (X100)

c) Pollen tubes reached the lower part of style after 3 days from pollination (X100)
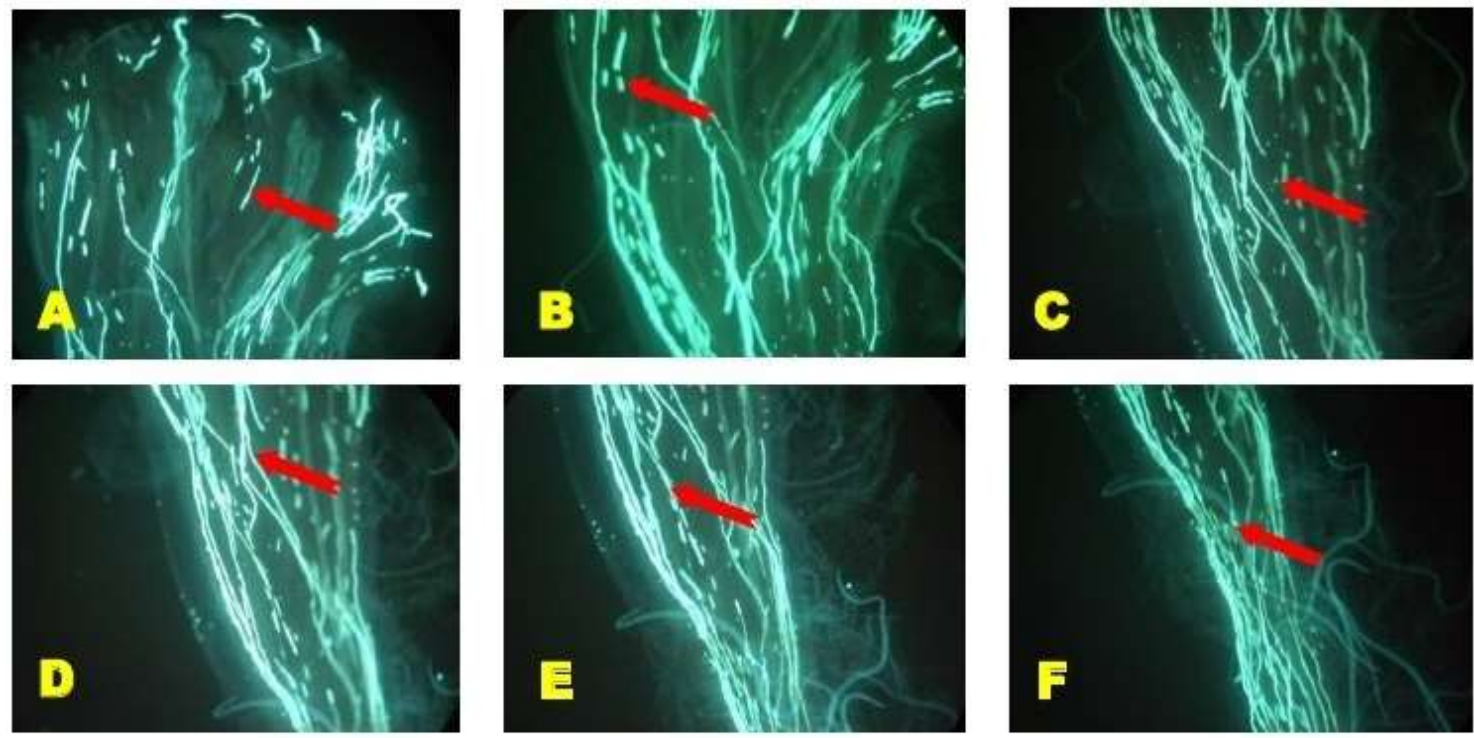

Fig. 2. Pollen tube characteristics after partial in compatible crosses (Anna*E25)

a) Pollen tubes were visible in the upper part of the style but has deposition of calluses along the tube (X100)

b) Pollen tubes grew slowly with heavy deposition of calluses (X100).

c,d,e) Some pollen tubes showed normal growth (X100)

f) Pollen tubes reached the end of the style 5 days from pollination (X100) 


\section{Self-compatibility}

Anna cultivar seemed to be self-incompatible (Fig. 3). However, the presence of short tubes from Anna was observed, these tubes could not penetrate the stigma of their own pistil as well as the twisting tube as shown in (Fig. 3A). On the other hand, most pollen tubes that developed through the styles marked by the decomposition of Callose along the tube that stopped $1 / 3$ of the style after 7 days of pollination. The pollen tube walls contain callous (1, 3-glucane) that binds to aniline blue during staining (Abd Elaziz et al 2017) Various degrees of partial exposed-incompatibility of growth of pollen tubes. Apple growers are largely self-contained (Broothaerts \& Van Nerum, 2003). Because fruit production is self-incompatible, it depends on insect activity, which is strongly influenced by weather conditions; thus, the production of irregular fruit is a continuous threat. An array of mechanisms can result in self-incompatibility. Self-pollen does not adhere to the stigma, but may not germinate, germinate, but cannot penetrate or expand in the style (Anne, 2007). Nearly all apple cultivars are reported to be either self-incompatible or semi-compatible and need cross-pollination to set fruit in marketable quantities (Garratt et al 2013; Matsumoto, 2014).
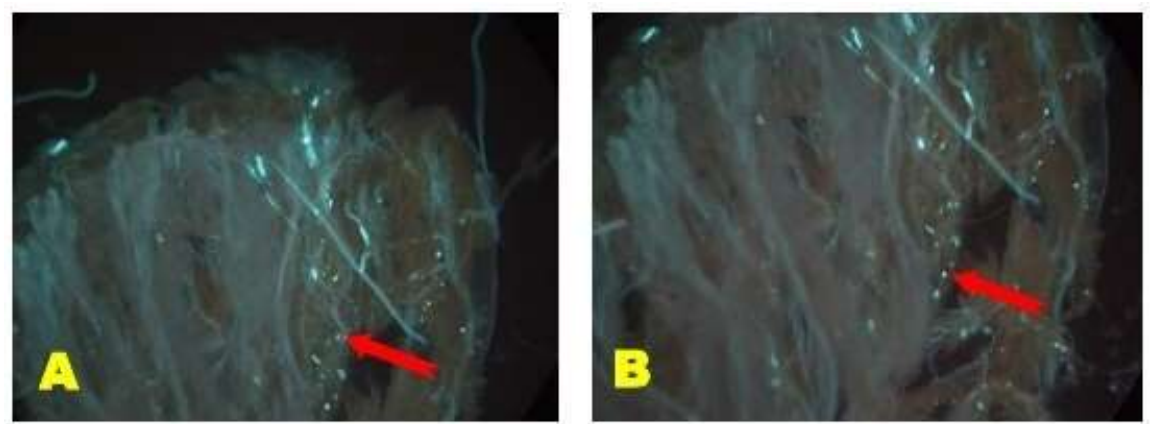

Fig. 3. Incompatible pollen tube growth characterization (self) a,b ). Poor pollen germination on the stigma (X100). Pollen tube has calluses in large quantities and plugs (X100). Pollen tube reached only to $1 \backslash 3$ length of style 5 days after pollination (X100).

Effect of the different treatments of pollination on the percentages of initial and final set of fruit

Table (2) showed that, percentages of initial and final fruits set after various treatments for pollination. The combinations of Anna $\times$ Dorsett Golden and Anna x Ein Shemer exhibited the highest percentage of initial and final fruit set included in the two seasons. However, initial and final set of fruit after Anna $\times$ E25 were generally less than the other two pollinizer Dorsett Golden and E25. Anna self pollination as well as a female parent gave the lowest initial percentage of fruit set in the first and second seasons. On the other side, Anna open pollination as well as a female parent gave the intermediate initial fruit set percentage in seasons one and the next.
Effect of the different pollination treatments on some fruit physical and chemical properties

Data in Tables (3 and 4): show the physical and chemical properties of fruit from the 2016 and 2017 seasons studied hybridization of apple cultivars. There were no significant differences in fruit weight within different combinations of crosses during the two seasons studied. The same trend was obtained also in fruit volume for the studied crosses. Concerning the fruit length and diameter there were no significant differences among all crosses except in 2017 season.

But it could be noticed that fruit weight with two last crossing treatments recorded lowest significant values in first season. Data in Table (4) shows that Dorsett Golden when use as a male parent gave the 
Table 2. Initial and final fruit set percentages of Ann apple cultivar after self, crossed by Dorsett Golden, E25, Ein Shemer pollens and open pollination in the two 2016 and 2017 seasons

\begin{tabular}{|c|c|c|c|c|c|c|c|}
\hline \multirow{2}{*}{$\begin{array}{c}\text { Pollinated } \\
\text { cultivar } \\
\text { ( Female) }\end{array}$} & \multirow{2}{*}{$\begin{array}{l}\text { Pollinizing } \\
\text { cultivar } \\
\text { ( Male ) }\end{array}$} & \multicolumn{3}{|c|}{ First Season } & \multicolumn{3}{|c|}{ Second Season } \\
\hline & & $\begin{array}{c}\text { No. of } \\
\text { flowers }\end{array}$ & $\begin{array}{c}\text { Initial } \\
\text { fruit set \% }\end{array}$ & $\begin{array}{c}\text { Final } \\
\text { fruit set } \%\end{array}$ & $\begin{array}{l}\text { No. of } \\
\text { flowers }\end{array}$ & $\begin{array}{c}\text { Initial } \\
\text { fruit set } \%\end{array}$ & $\begin{array}{c}\text { Final } \\
\text { fruit set } \%\end{array}$ \\
\hline \multirow{5}{*}{ Anna } & $\begin{array}{l}\text { Dorsett } \\
\text { Golden }\end{array}$ & 348 & $57.19 \mathrm{~A}$ & $35.26 \mathrm{~A}$ & 320 & $56.10 \mathrm{~A}$ & $33.79 \mathrm{~A}$ \\
\hline & E25 & 327 & $6.07 \mathrm{C}$ & $3.32 \mathrm{C}$ & 315 & $5.55 \mathrm{C}$ & $3.45 \mathrm{C}$ \\
\hline & Ein Shemer & 391 & $45.01 \mathrm{~A}$ & $25.73 \mathrm{~A}$ & 380 & $42.29 \mathrm{~A}$ & $24.87 \mathrm{~A}$ \\
\hline & $\begin{array}{l}\text { Anna } \\
\text { (Self) }\end{array}$ & 171 & $11.32 \mathrm{~B}$ & $4.84 \mathrm{C}$ & 165 & $11.53 \mathrm{~B}$ & $4.66 \mathrm{C}$ \\
\hline & $\begin{array}{c}\text { Open } \\
\text { (Control) }\end{array}$ & 320 & $15.88 \mathrm{~B}$ & $10.61 \mathrm{~B}$ & 325 & $16.92 \mathrm{~B}$ & $10.56 \mathrm{~B}$ \\
\hline
\end{tabular}

Values having the same letter within the same column are not statically different at $5 \%$ level.

Table 3. Effect of different pollination treatments on fruit weight, fruit volume, fruit length and fruit diameter of studied apple cultivars during two seasons 2016 and 2017

\begin{tabular}{|c|c|c|c|c|c|c|c|c|c|}
\hline \multicolumn{2}{|c|}{ Hybridization } & \multicolumn{2}{|c|}{$\begin{array}{c}\text { Fruit weight } \\
(\mathrm{g})\end{array}$} & \multicolumn{2}{|c|}{$\begin{array}{c}\text { Fruit volume } \\
\left(\mathrm{cm}^{3}\right)\end{array}$} & \multicolumn{2}{|c|}{$\begin{array}{c}\text { Fruit length } \\
(\mathrm{cm})\end{array}$} & \multicolumn{2}{|c|}{$\begin{array}{l}\text { Fruit diameter } \\
(\mathbf{c m})\end{array}$} \\
\hline $\begin{array}{c}\text { Female } \\
\text { Parent } \\
\end{array}$ & $\begin{array}{c}\text { Male } \\
\text { Parent } \\
\end{array}$ & $\begin{array}{c}\text { Season } \\
2016 \\
\end{array}$ & $\begin{array}{c}\text { Season } \\
2017 \\
\end{array}$ & $\begin{array}{c}\text { Season } \\
2016 \\
\end{array}$ & $\begin{array}{c}\text { Season } \\
2017 \\
\end{array}$ & $\begin{array}{c}\text { Season } \\
2016 \\
\end{array}$ & $\begin{array}{c}\text { Season } \\
2017 \\
\end{array}$ & $\begin{array}{c}\text { Season } \\
2016 \\
\end{array}$ & $\begin{array}{c}\text { Season } \\
2017 \\
\end{array}$ \\
\hline Anna & $\begin{array}{c}\text { Dorsett } \\
\text { Golden } \\
\text { Ein } \\
\text { Shemer } \\
\text { E25 } \\
\text { Anna } \\
\text { Open } \\
\text { (Control) }\end{array}$ & $\begin{array}{l}98.20 \mathrm{~A} \\
99.27 \mathrm{~A} \\
98.57 \mathrm{~A} \\
89.50 \mathrm{~B} \\
89.80 \mathrm{~B}\end{array}$ & $\begin{array}{l}100.0 \mathrm{~A} \\
97.87 \mathrm{~A} \\
83.83 \mathrm{~B} \\
99.40 \mathrm{~A} \\
93.43 \mathrm{~A}\end{array}$ & $\begin{array}{l}131.7 \mathrm{~A} \\
120.0 \mathrm{AB} \\
113.3 \mathrm{~B} \\
108.3 \mathrm{~B}\end{array}$ & $\begin{array}{l}121.7 \mathrm{~A} \\
121.7 \mathrm{~A} \\
109.1 \mathrm{~A} \\
125.0 \mathrm{~A} \\
111.7 \mathrm{~A}\end{array}$ & $\begin{array}{l}58.20 \mathrm{~B} \\
63.30 \mathrm{AB} \\
69.83 \mathrm{~A} \\
59.53 \mathrm{AB}\end{array}$ & $\begin{array}{l}60.47 \mathrm{~A} \\
56.03 \mathrm{~A} \\
61.70 \mathrm{~A} \\
60.97 \mathrm{~A}\end{array}$ & $\begin{array}{l}59.50 \mathrm{~A} \\
59.27 \mathrm{~A} \\
58.77 \mathrm{~A} \\
55.47 \mathrm{~A}\end{array}$ & $\begin{array}{l}61.17 \mathrm{~A} \\
60.67 \mathrm{~A} \\
56.13 \mathrm{~A} \\
59.97 \mathrm{~A} \\
59.53 \mathrm{~A}\end{array}$ \\
\hline
\end{tabular}

Values having the same letter within the same column are not statically different at $5 \%$ level. 
Table 4. Effect of different pollination treatments on Number of seeds / fruit, Fruit pulp thickness, TSS \% and Total acidity \% of studied apple cultivars during two seasons 2016 and 2017

\begin{tabular}{|c|c|c|c|c|c|c|c|c|c|}
\hline \multicolumn{2}{|c|}{ Hybridization } & $\begin{array}{c}\text { Number of seeds } \\
\text { / fruits }\end{array}$ & \multicolumn{2}{c|}{$\begin{array}{c}\text { Fruit pulp } \\
\text { thickness (cm) }\end{array}$} & \multicolumn{2}{c|}{ TSS \% } & \multicolumn{2}{c|}{ Total acidity \% } \\
\hline $\begin{array}{c}\text { Female } \\
\text { Parent }\end{array}$ & $\begin{array}{c}\text { Male } \\
\text { Parent }\end{array}$ & $\begin{array}{c}\text { Season } \\
\mathbf{2 0 1 6}\end{array}$ & $\begin{array}{c}\text { Season } \\
\mathbf{2 0 1 7}\end{array}$ & $\begin{array}{c}\text { Season } \\
\mathbf{2 0 1 6}\end{array}$ & $\begin{array}{c}\text { Season } \\
\mathbf{2 0 1 7}\end{array}$ & $\begin{array}{c}\text { Season } \\
\mathbf{2 0 1 6}\end{array}$ & $\begin{array}{c}\text { Season } \\
\mathbf{2 0 1 7}\end{array}$ & $\begin{array}{c}\text { Season } \\
\mathbf{2 0 1 6}\end{array}$ & $\begin{array}{c}\text { Season } \\
\mathbf{2 0 1 7}\end{array}$ \\
\hline $\begin{array}{c}\text { Dorsett } \\
\text { Golden } \\
\text { Anna }\end{array}$ & $6.333 \mathrm{~A}$ & $6.333 \mathrm{~A}$ & $1.900 \mathrm{~B}$ & $1.967 \mathrm{AB}$ & $12.67 \mathrm{~A}$ & $12.00 \mathrm{~A}$ & $0.589 \mathrm{~A}$ & $0.473 \mathrm{~A}$ \\
& $\begin{array}{c}\text { Ein } \\
\text { Shemer } \\
\text { E25 } \\
\text { Anna }\end{array}$ & $2.000 \mathrm{~B}$ & $6.333 \mathrm{~A}$ & $1.800 \mathrm{~B}$ & $2.100 \mathrm{~A}$ & $12.00 \mathrm{AB}$ & $12.33 \mathrm{~A}$ & $0.504 \mathrm{BC}$ & $0.491 \mathrm{~A}$ \\
& $\begin{array}{c}2.000 \mathrm{~B} \\
\text { Open } \\
\text { (Control) }\end{array}$ & $2.333 \mathrm{~B}$ & $3.000 \mathrm{~B}$ & $1.933 \mathrm{~B}$ & $1.633 \mathrm{C}$ & $12.17 \mathrm{AB}$ & $12.50 \mathrm{~A}$ & $0.491 \mathrm{BC}$ & $0.491 \mathrm{~A}$ \\
& $3.000 \mathrm{~B}$ & $1.633 \mathrm{~B}$ & $1.700 \mathrm{BC}$ & $11.83 \mathrm{~B}$ & $12.50 \mathrm{~A}$ & $0.451 \mathrm{C}$ & $0.487 \mathrm{~A}$ \\
\hline
\end{tabular}

Values having the same letter within the same column are not statically different at $5 \%$ level.

highest number of seeds per fruit compared with the other pollinizer in the two studied seasons. On the other side, all pollinizer gave the lowest of fruit pulp thickness value than self-pollination. Concerning the chemical properties of fruits from different crosses under study in 2016 and 2017 seasons. In general, the TSS values of these crosses ranged from $11.83 \%$ to $12.83 \%$. Slight significant differences could be noticed among all the tested crosses during all tested seasons. On the other hand, acidity ranged between $(0.45 \%-0.58 \%)$ for all crosses. The highest acidity was found in hybrid Anna $\times$ Dorsett Golden except in the first season. Bashir et al (2010) recorded highest seeds numbers in the cross 'Fuji' × 'Spartan' while the minimum number was obtained from the 'Quinte' $x$ 'Spartan' cross. The maximum total soluble solids were found in 'Jonadel' $\times$ 'Royal Gala'; the minimum in 'Quinte' $x$ 'Royal Gala'. For commercial development, a total of two intercompatible cultivars with synchronous flowering was recommended (Garratt et al 2013; Goldway et al 2012). Matsumoto et al (2008) recorded a substantial decrease in fruit set with growing the distance between the pollinator and the main cultivars and the suggested pollinators should not exceed $10 \mathrm{~m}$ from the target crops (Matsumoto et al 2008). Gheorghe et al (2009) Total acidity values ranged from 0.127 to 0.345 percent, low values below the maximum allowable 0.31 percent. Low acidity determines good quality for human consumption.

\section{CONCLUSION}

From the results of this study, it can be inferred that, 'Anna' apple is a self-incompatible cultivar and requires a pollinator. Dorsett Golden apple cultivar is the best pollinizer for the Anna apple cultivar for were observed with Dorsett in compare to other cultivars Ein shemer and E25, the high percentage of the viability of pollen grains in T.T.C after $24 \mathrm{~h}$., the initial and final percentage of the fruit after the crosses.

\section{REFERENCES}

A.O.A.C. 1990. Association of Official of Agriculture Chemists, Official Methods of Analysis. $11^{\text {th }}$ Ed. Published by the A.O.A.C. Washington D. C., U.S.A, pp. 915-918, 1048\&1058.

Abd Elaziz Y.S.G., Naglaa H. Shakweer and Gehan A.M. ElHadidy 2017. Evaluation of Pioneer and Hollywood plum cultivars under sandy soil conditions in Egypt. Bull. Fac. Agric. Cairo Univ., 68, 411-424.

Abou El-Nasr N.M., Abou Rawash M., El-Masry H. and Ebeed S. 1997. Studies on pollination, chemical emasculation, and sexual compatibility between some mango cultivars. Annals Agric. Sci., Ain Shams Univ., Cairo, Egypt 42, 557571. 
Anne L.J. 2007. Methods for determining compatibility and pollination or efficiency in temperate fruit species. Fruit, Vegetable and Cereal Sci. and Biotechnology. Global Sci. Book, pp. 2638.

Bashir R., Sharma G. and Sharma N. 2010. Studies on fruit set and fruit characteristics as affected by different pollinizers in apple (Malus $\mathrm{x}$ domestica Borkh). Adv. Hort. Sci. 24(2), 137144.

Broothaerts W. and Van Nerum I. 2003. Apple self-incompatibility genotypes: an overview. Acta Hort., 622, 379-387.

Ciprian P., Viorel M., loana M., Lorent J. and Mugur C. 2012. The Rate of Pollen Germination and the Pollen Viability at Ten Apple Cultivars in the Climatic Conditions of Transylvania. Bulletin UASVM Horticulture, 69(1), 417-418.

De Nettancourt D. 2001. Incompatibility and incongruity in wild and cultivated plants (Vol. 3). Springer Science \& Business Media.

Duncan D.B. 1955. Multiple ranges and multiple tests. Biometrics, 11, 1- 24.

Frankel R., Galun E. and Linskens H.F. 1977. Allogamy, In: R. Frankel, E. Galun, and H.F. Linsken s (eds.). Pollination mechanisms, reproduction, and plant breeding. Springer- Verlag, New York, p. 67.

Garratt M.P.D., Truslove C.L., Coston D.J., Evans R.L., Moss E.D., Dodson C. and Potts S.G. 2013. Pollination deficits in UK apple orchards. J. Pollinat. Ecol. 11, 1- 6.

Gheorghe C., Gabriela N. and Gina D. 2009. Chemical Composition of the Fruits of Several Apple Cultivars Growth as Biological Crop. Not. Bot. Hort. Agrobot. Cluj 37(2), 161-164.

Goldway M., Stern R., Zisovich A., Raz A., Sapir G., Schnieder D. and Nyska R. 2012. The selfincompatibility fertilization system in Rosaceae: Agricultural and genetic aspects. Acta Hort. 967, 77.

Hegedûs A. 2006. Review of the self-incompatibility in apple (Malus $\times$ domestica Borkh., syn.: Malus pumila Mill.). Int. J. of Horticultural Sci., 12(2), 31-36.
Hua Z.H., Fields A. and Kao T.H. 2008. Biochemical models for S-RNase-based self-incompatibility. Molecular Plant 1(4), 575-585.

Ishiyama M., Kitayama H., Sato T., Ishizawa K., Nakamura Y., Suzuki C. and Yamada M. 1995. Field pollination tests in apple (in Japanese with English summary). Bul. Aomori Apple Expt. Sta. 28, 1- 21.

Kho Y.O. and Baer J. 1970. Die fluoresezenzmikroskopie in der botanischen forschung. Zeiss Inf., 18, 54-57.

Maklad M.F. 2015. Studies on sexual compatibility and or incompatibility in langara mango cultivar. Egypt. J. Plant breed. 19(3), 343-356.

Maryam B. and Ahmad E. 2019. Self-Incompatibility Alleles in Iranian Pear Cultivars. Former PhD student at Univ. of Bu-Ali Sina.

Matsumoto S. 2014. Apple pollination biology for stable and novel fruit production: Search system for apple cultivar combination showing incompatibility, semi compatibility, and full-compatibility based on the S-RNase allele database. IntI. J. Agron. Article ID 138271: 9.

Matsumoto S., Eguchi T., Maejima T. and Komatsu H. 2008. Effect of distance from early flowering pollinizers 'Maypole' and 'Dolgo' on 'Fuji' fruit set. Sci. Hort. 117(2), 151-159.

Oberle G.D. and Waston R. 1952. A method for evaluating pollen production of fruit varieties. Proc. Amer. Soc. Hort. Sci. 59, 263-265.

Orcheski B. and Brown S. 2012. A Grower's Guide to Self and Cross Incompatibility in Apple. New York Fruit Quarterly.

Sakurai K., Susan K.B. and Weeden N. 2000. Self-incompatibility Alleles of Apple Cultivars and Advanced Selections. HortScience 35(1), 116-119.

Snedecor G.W. and Cochran W.G. 1972. Statistical Methods. $6^{\text {th }}$ ed. The lowa State Univ., Press, lowa, USA, 593 p.

Way R.D. 1995. Pollination and fruit set of fruit crops. Cornell Coop. Ext. Info. Bul. 237 p.

Zisovich A.H., Raz A., Stern R.A. and Goldway M. 2010. Syrian pear (Pyrus syriaca) as a pollinator for European pear (Pyrus communis) cultivars. Scientia Horticulturae, 125(3), 256262. 
مجلة اتحاد الجامعات العربية للعلوم الزراعية، جامعة عين شمس، القاهرة، مصر مجلد(28)، عدد(2)، 545-537، 2020

Website: http://ajs.journals.ekb.eg

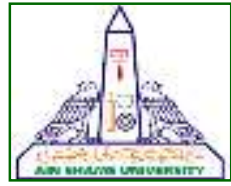

دراسات على التوافق وعقد وجودة الثمار بإستخدام ملقحات مختلفة لصنف التفاح الأنا

مى إبراهيم أنور1" - نظمى عبد الحميد عبد الغنى2 - محمود فتحى مقلد2 - نهلة عبد الفتاح عواد 1

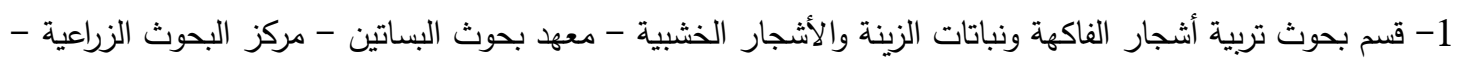

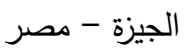

2- قسم البساتين - كلية الزراعة - جامعة عين شمس - صندوق بريد 68 - حدائق شبرا 11241 - القاهرة - مصر

*Corresponding author: mahmoud maklad@agr.asu.edu.eg

Received 18 June, 2020

Accepted 24 August, 2020

من التوافق الخلطى عند تهجينها داخل أنسجة قلم الآنا.

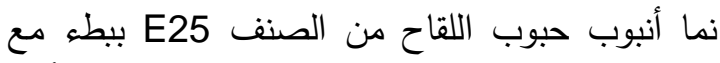

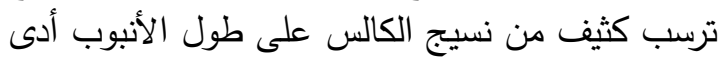

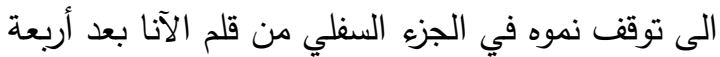

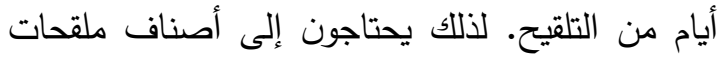

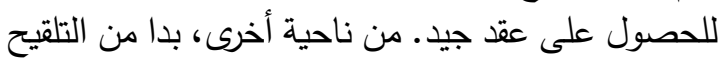

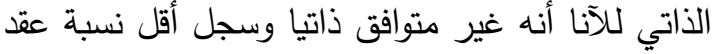

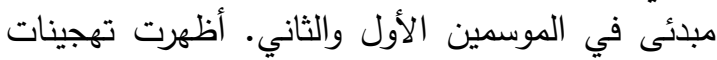
Anna × Dorsett Golden

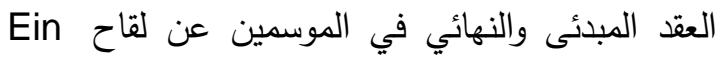
Shemer

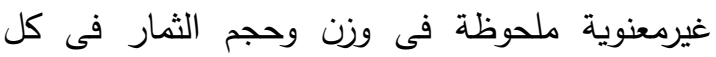
التلقيحات. أعلى نسبة حموضة كانت مونئ وحودة في ثمار الهجين Anna × Dorsett Golden خاصة في في في الموسم الأول. قيم TSS لكل التلقيحات لم تكن مرتفعة

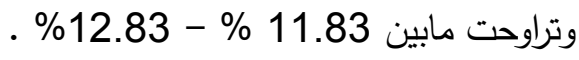

الكلمات المفتاحية: أصناف التفاح، الأنا، التوافق الخلطى، حيوية حبوب اللقاح، عقد الثمار، جودة الثمار الثان التراف

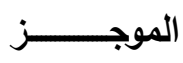

التفاح (Malus domestica) ينتمى الى العائلة

Rosaceae

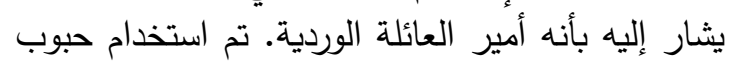

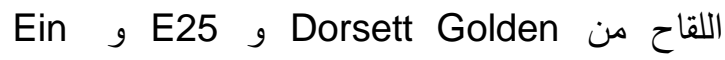
Shemer للتحقق من مدى توافقهما وعدم توافقهما مع التح الصنف آنا تحت الظروف المناخية المصرية خدية خلال

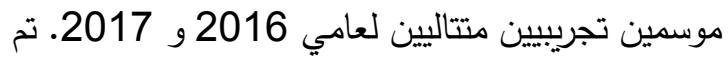

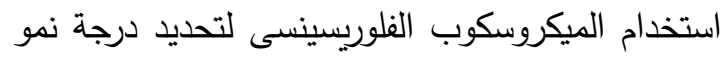
أنبوب اللقاح في أنسجة القلم بعد معاملات التلقيح

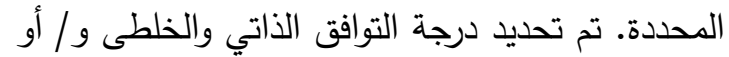

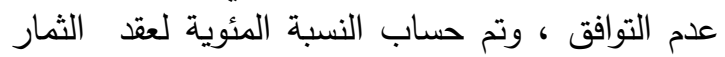

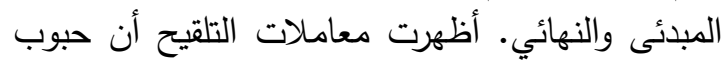

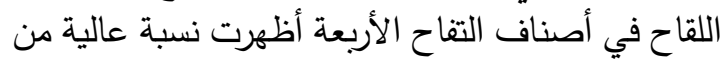

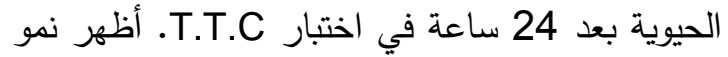

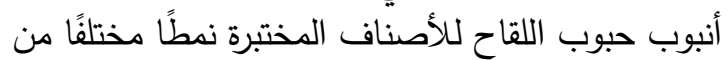

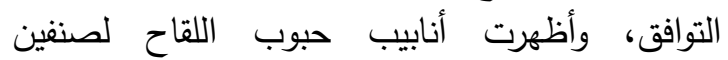
Din Shemer و Dorsett Golden

تحكيم: ا.د حسن محمد فاضل الوكيل

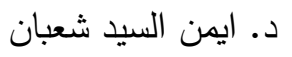

